\title{
AKRUAL
}

Jurnal Akuntansi

http://fe.unesa.ac.id/ojs/index.php/akrl

\section{ANALISIS INDIKATOR YANG MEMPENGARUHI AUDITOR DALAM MEMBERIKAN OPINI GOING CONCERN PADA SUATU PERUSAHAAN DENGAN PENDEKATAN ISA 570 \\ (PERUSAHAAN YANG TERDAFTAR DI BEI PERIODE 2014)}

\author{
Lintang Trenggono \\ Mahasiswa Jurusan Akuntansi Fakultas Ekonomi Universitas Negeri Surabaya \\ Email: ltrenggono@gmail.com \\ Ni Nyoman Alit Triani \\ Jurusan Akuntansi Fakultas Ekonomi Universitas Negeri Surabaya \\ Email: trianialit8@gmail.com
}

\begin{abstract}
This study aimed to analyze the indicators that affect the auditor in providing a going concern audit opinion to the companies that listed on the Indonesian Stock Exchange in 2014. The variables in this study is the financial condition of the company, the company's growth, debt default, the current ratio, RoA, audit opinion in previous year, the companies' compliance with laws and regulations. The sample in this study are all companies listed on the Indonesian Stock Exchange (BEI) in 2014 using saturation sampling technique and acquired 485 companies that meet the criteria of representatif sample. The results ofresearch conducted by using the test model regression logistic indicates that the variable debt default and the audit opinion in previous year have an affects to the providing of going concern audit opinion and variable financial condition of the company, the company's growth, the current ratio, RoA, companies' compliance with laws and regulations have no effect tothe providing of going concern audit opinion.
\end{abstract}

Keywords: going concern audit opinion, debt default, RoA, audit opinion in previous year, the companies' compliance with laws and regulations.

\begin{abstract}
Abstrak
Penelitian ini bertujuan untuk menganalisis indikator yang mempengaruhi auditor dalam memberikan opini audit going concern pada perusahaan yang terdaftar di Bursa Efek Indonesia pada tahun 2014. Variabel dalam penelitian ini adalah kondisi keuangan perusahaan, pertumbuhan perusahaan, debt default, rasio lancar, rasio RoA, opini audit tahun sebelumnya, kepatuhan perusahaan pada hukum dan peraturan. Sampel dalam penelitian ini adalah seluruh perusahaan yang terdaftar di Bursa Efek Indonesia (BEI) pada tahun 2014 dengan menggunakan teknik purposive sampling dan diperoleh 485 perusahaan yang memenuhi kriteria sampel representatif. Hasil penelitian yang dilakukan dengan menggunakan logistik uji model regresi menunjukkan bahwa debt default variabel dan opini audit tahun sebelumnya memiliki pengaruh dalam pemberiaan opini audit going concern dan variabel kondisi keuangan perusahaan, pertumbuhan perusahaan, rasio lancar, rasio RoA, dan
\end{abstract}


kepatuhan perusahaan pada hukum dan peraturan tidak berpengaruh dalam pemberian opini audit going concern.

Kata kunci: opini audit going concern, debt default, rasio RoA, opini audit tahun sebelumnya, kepatuhan perusahaan pada hukum dan peraturan.

\section{PENDAHULUAN}

Dalam setiap pendirian sebuah perusahaan, pasti mempunyai visi dan misi kegiatan bisnis yang sama dalam mencari keuntungan/profit di dalam bidang usahanya namun keberadaan suatu perusahaan tentu saja tidak akan pernah lepas dari pengaruh dinamis lingkungan perusahaan baik internal maupun eksternal yang berdampak pada meningkatnya persaingan antar perusahaan yang hampir disetiap perusahaan akan menimbulkan suatu kecenderungan dimana perusahaan memiliki kesulitan dalam melaksanakan visi dan misi kegiatan bisnis yang paling mendasar, yaitu menjaga kelangsungan hidup perusahaannya (going concern).

ISA (International Standard on Auditing) yang telah diterbitkan oleh IAASB (International Auditing and Assurance Standards Boards) melalui IFAC (International Federation of Accountant) pada tahun 2009 merupakan sebuah langkah struktural dalam meningkatkan kualitas bukti audit yang pada akhirnya dapat meningkatkan kualitas audit. Di Indonesia sendiri, pengadopsian ISA dimulai pada periode 1 Januari 2013. Tata cara penggunaan asumsi kesinambungan usaha (going concern) sendiri terdapat pada ISA 570. ISA 570 merupakan sebuah petunjuk mengenai tanggung jawab auditor dalam audit atas laporan keuangan berkenaan dengan penggunaaan asumsi "usaha yang berkesinambungan" dan penilaian manajemen mengenai kemampuan entitas untuk melanjutkan usahanya (Tuanakotta, 2014:220). Pada ISA 570 terdapat tiga tahapan audit atas kesinambungan usaha yang terdiri dari tahap penilaian resiko, respon atas resiko, dan tahap pelaporan.

Pertimbangan yang diambil oleh seorang auditor dalam memberikan opini audit going concern pada suatu perusahaan merupakan sebuah sinyal peringatan mengenai kelangsungan hidup suatu perusahaan atas implikasi dari identifikasi peristiwa atau kondisi yang dapat menimbulkan keraguan mengenai kemampuan perusahaan untuk melanjutkan usahanya sebagai usaha yang berkesinambungan dengan mengindikasikan indikator keuangan, operasional, dan lain-lain.

Indikator keuangan merupakan faktor yang berhubungan dengan kondisi keuangan suatu perusahaan yang diukur dengan menggunakan pengujian prosedur analitik sebagaimana diharuskan dalam ISA 520 tentang "Analytical Procedures" dalam proses audit atas laporan keuangan yang dilakukan baik pada saat tahap perencanaan, pengerjaan, maupun tahap penyelesaian audit. Prosedur analitik sendiri merupakan prosedur yang dilakukan auditor untuk memperoleh pemahaman terhadap bisnis klien (Arens et.al, 2008:191). Secara umum pengujian prosedur analitik dapat dilakukan dengan cara rasio keuangan dan pertumbuhan perusahaan, debt default, serta financial distress. Sedangkan indikator operasional dan lainlain perusahaan merupakan faktor non financial yang lebih banyak berkaitan dengan opini audit tahun sebelumnya, serta kepatuhan perusahaan pada hukum dan peraturan.

Rasio likuiditas sering digunakan dalam memprediksi kepailitan, going concern juga sangat dipengaruhi oleh likuitas. Hal ini didukung oleh Hadad et al (2003); Januarti dan Fitrianasari (2008); LaSalle dan Anandarajan (1996); Bruynseels dan Willekens(2006). Financial distress juga akan sangat berpengaruh dalam pemberian opini audit going concern, Fanny dan Saputra (2005).

Ketika jumlah hutang perusahaan sudah sangat besar, maka aliran kas perusahaan tentunya banyak dialokasikan untuk menutupi hutangnya, sehingga mengganggu kelangsungan operasi perusahaan. Apabila hutang ini tidak mampu dilunasi, maka kreditor akan memberikan status default. Status default dapat meningkatkan kemungkinan auditor 
mengeluarkan laporan going concern. Seperti yang tercantum dalam PSA 30, indikator going concern yang banyak digunakan auditor dalam memberikan keputusan opini audit adalah kegagalan dalam memenuhi kewajiban hutangnya (default). Hal ini didukung oleh pernyataan dari Chen dan Church (1992) .

Dari latar belakang yang telah diuraikan diatas, dirumuskan beberapa masalah sebagai berikut :

1. Apakah indikator keuangan perusahaan (kondisi keuangan perusahaan, pertumbuhan perusahaan, debt default, dan rasio keuangan) berpengaruh terhadap pemberian opini audit going concern.

2. Apakah indikator operasional dan lain-lain perusahaan (opini audit tahun sebelumnya serta kepatuhan perusahaan pada hukum dan peraturan) berpengaruh terhadap pemberian opini audit going concern.

\section{KAJIAN PUSTAKA \\ Going Concern}

Going concern adalah kelangsungan hidup suatu perusahaan. Dengan adanya going concern maka suatu perusahaan dianggap mampu mempertahankan kegiatan usahanya untuk jangka waktu kedepan dan tidak ada rencana likuidasi dalam jangka waktu pendek atau berhenti beroperasi. Setyawan (2006) menyatakan, going concern sebagai asumsi bahwa perusahaan dapat mempertahankan hidupnya secara langsung akan mempengaruhi laporan keuangan. Laporan keuangan yang disiapkan menggunakan dasar going concern kemungkinan akan berbeda substantial dengan laporan keuangan yang disiapkan pada asumsi bahwa perusahaan tidak going concern. Laporan keuangan yang disiapkan pada dasar going concern akan mengasumsikan bahwa perusahaan akan bertahan melebihi jangka waktu pendek.

International Standard on Auditing (ISA) yang dikeluarkan oleh International Federation of Accountants (IFAC) merupakan panduan audit di negara-negara anggota IFAC. IFAC telah mengeluarkan ISA No. 570 tentang "Going Concern" yang berlaku efektif sejak tahun 2004. ISA No.570 menegaskan bahwa tanggung jawab auditor eksternal hanya melakukan pertimbangan atas ketetapan asumsi going concern yang digunakan oleh manajemen dalam menyusun laporan keuangan. Going concern entitas yang diaudit harus dapat dipertahankan paling tidak dua belas bulan setelah tanggal neraca. ISA No.570.10 jika tidak terdapat penjelasan mengenai adanya ketidakpastian oleh auditor eksternal pada opininya, tidaklah menjadi jaminan bahwa kelangsungan hidup perusahaan tidak akan bermasalah.

ISA 570 telah menjadi petunjuk bagi para auditor mengenai tanggung jawab auditor dengan penggunaan asumsi "usaha berkesinambungan" dan penilaian manajemen mengenai kemampuan entitas untuk melanjutkan usahanya sebagai usaha berkesinambungan. Di dalam ISA 570.2, dalam hal asumsi usaha berkesinambungan, suatu entitas dianggap mempunyai usaha yang berkesinambungan dalam waktu dekat di masa mendatang.

Laporan keuangan yang bertujuan umum dibuat dengan dasar kesinambungan usaha, kecuali jika manajemen mempunyai niat/rencana melikuidasi entitas itu atau berhenti beroperasi, atau tidak ada alternatif yang realistis kecuali membubarkannya. Laporan keuangan yang bertujuan khusus dapat atau dapat tidak dibuat dengan kerangka pelaporan keuangan dimana dasar kesinambungan usaha itu relevan. Tujuan Auditor dalam audit kesinambungan usaha sendiri menurut ISA 570.9 antara lain :

1. Memperoleh bukti audit yang cukup dan tepat tentang tepat/tidaknya penggunaan asumsi kesinambungan usaha oleh manajemen dalam membuat laporan keuangan;

2. Menyimpulkan, berdasarkan bukti audit yang diperoleh, apakah ada ketidakpastian yang material mengenai peristiwa atau kondisi yang mungkin menimbulkan keraguan mengenai 
kemampuan entitas untuk melanjutkan usahanya sebagai usaha yang berkesinambungan; dan

3. Menentukan implikasinya terhadap laporan auditor.

Dalam pelaksanaan prosedur audit auditor dapat mengidentifikasi informasi mengenai kondisi atau peristiwa tertentu yang, jika dipertimbangkan secara keseluruhan, menunjukkan tanda-tanda kebangkrutan serta kesangsian besar tentang kemampuan entitas dalam mempertahankan kelangsungan hidupnya dalam jangka waktu pantas. Indikator yang menggambarkan keraguan besar mengenai asumsi kesinambungan usaha antara lain : 1) Indikator keuangan; 2) Indikator Operasional; 3) Lain-lain.

Peristiwa atau kondisi dapat diidentifikasi sebagai sebab timbulnya keraguan besar mengenai kemampuan entitas dalam melanjutkan usahanya secara berkesinambungan. ketidakpastian material terjadi jika besaran dari dampak potensial yang dalam suatu pendapat seorang auditor harus ada pengungkapan yang tepat mengenai sifat dan implikasi dari ketidakpastian agar tercapai sebuah penyajian yang wajar dari laporan keuangan.

Rencana manajemen untuk tindakan di masa mendatang mengenai masalah kesinambungan usaha yang berkaitan erat dengan peristiwa/kondisi di atas umumnya membahas satu atau beberapa strategi tentang: Melikuidasi aset; Meminjam uang atau merustrukturisasi utang; Mengurangi atau menunda pengeluaran; Merestrukturisasi operasi, termasuk produk dan jasa; Mengupayakan merger atau acquisition; Meningkatkan modal.

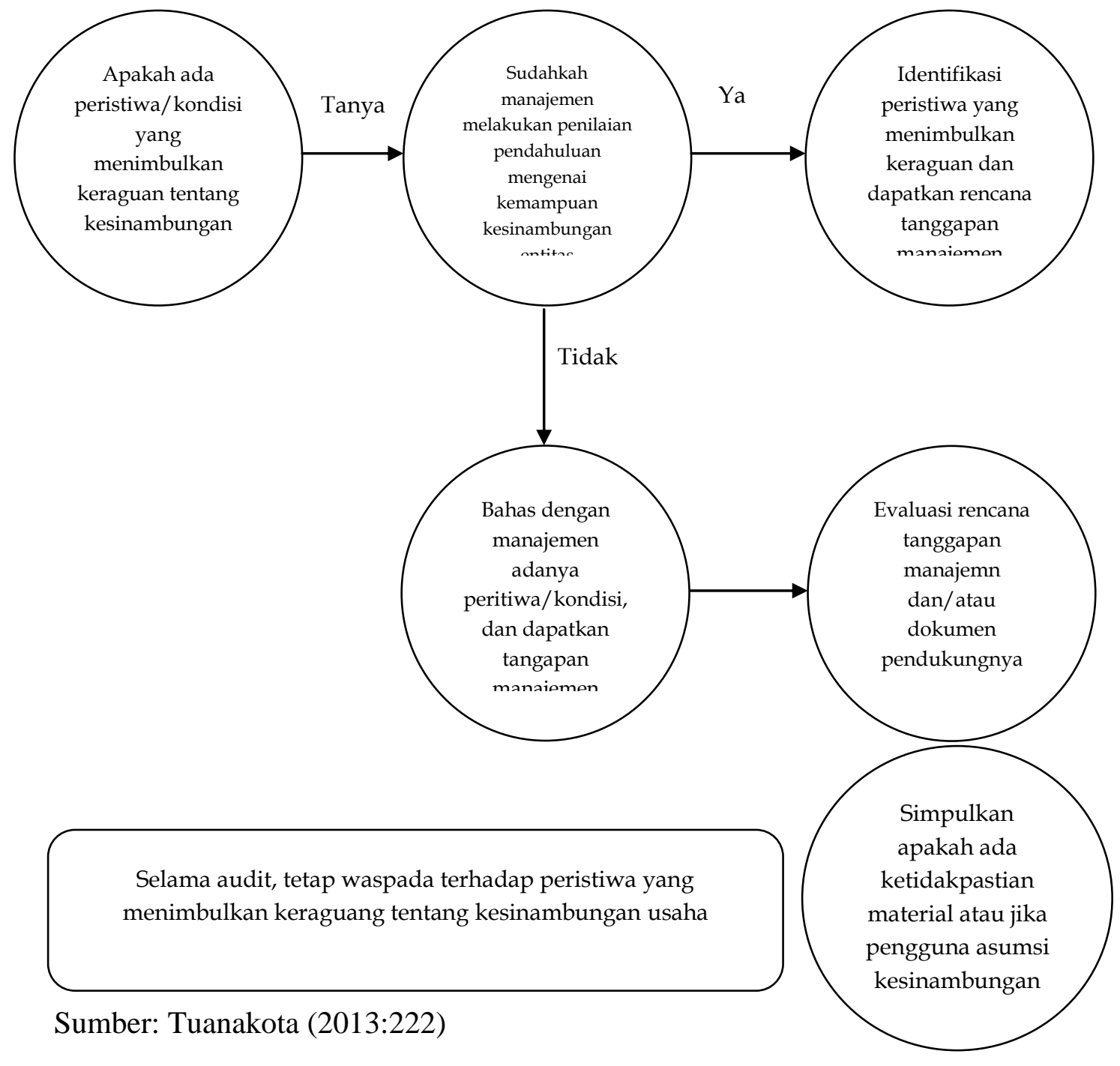




\section{Gambar 1. Skema Prosedur dalam Penilaian Risiko atas Kesinambungan Usaha Berdasarkan ISA 570}

Evaluasi atas kemampuan entitas bisnis untuk mempertahankan kelangsungan hidupnya, dilakukan oleh auditor eksternal atas data keuangan dan non-keuangan yang di peroleh. Bukan tidak mungkin terdapat faktor eksternal yang tidak dapat diprediksi sebelumnya, yang mengakibatkan suatu entitas bisnis mengalami kebangkrutan. Jika itu terjadi, maka hal tersebut diluar tanggung jawab auditor eksternal.

Opini audit dengan modifikasi mengenai going concern adalah opini audit selain opini wajar tanpa pengecualian yang mengindikasikan bahwa dalam penilaian auditor terdapat risiko perusahaan tidak dapat mempertahankan kelangsungan hidupnya (Ramadhany, 2004). Dari sudut pandang auditor, keputusan dalam memodifikasi pendapat melibatkan beberapa tahap analisis. Auditor harus mempertimbangkan hasil operasi perusahaan, kondisi ekonomi yang mempengaruhi perusahaan, kemampuan perusahaan dalam membayar utang, dan kebutuhan likuiditas di masa yang akan datang (Praptitorini dan Januarti, 2007).

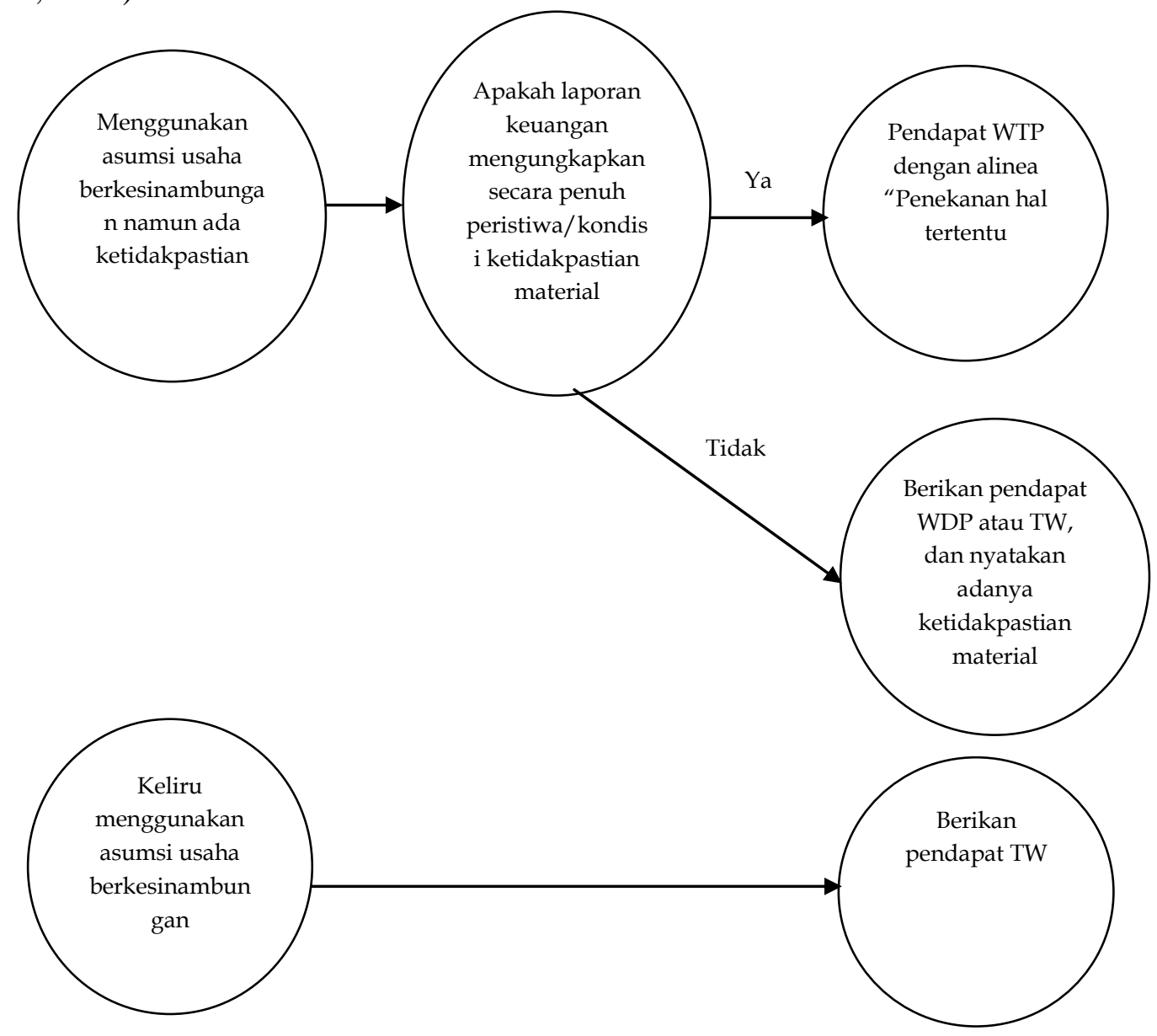

Sumber: Tuanakota $(2013: 230)$

Gambar 2. Skema Pembentukan Kesimpulan Auditor dan Pelaporan Mengenai Kesinambungan Usaha Berdasarkan ISA 570 


\section{Kondisi Keuangan}

Kondisi keuangan perusahaan dapat menggambarkan tingkat kesehatan perusahaan yang sesungguhnya (Ramadhany, 2004). Mckeown et al (1990) menemukan bahwa auditor hampir tidak akan pernah memberikan opini audit going concern pada perusahaan yang tidak mengalami kesulitan keuangan. Carcello dan Neal (2000) menyatakan bahwa semakin buruk kondisi keuangan perusahaan maka semakin besar probablitias perusahaan menerima opini going concern. Dengan menggunakan model Altman Z-score penelitian Ramadhany selaras dengan penelitian Mckeown et al (1990).

Kondisi keuangan pada penelitian ini diukur dengan model pengukuran Model Altman Modification. Revisi yang dilakukan oleh Altman sebelumnya pada model Altman Z-Scores yang pertama, telah di modifikasi oleh Altman et al (1995) untuk melakukan penyesuaian agar model prediksi Altman Modificated bisa diterapkan pada semua jenis perusahaan selain perusahaan manufaktur baik perusahaan privat maupun go public. Menurut Lukviarman dan Ramadhani (2009), didalam model Z-score modifikasi, Altman et al mengeliminasi variable X5 (sales/total asset.) karena rasio ini sangat bervariatif pada industri dengan ukuran asset yang berbeda- beda. Berikut persamaan Z-Score yang model Altman Modifikasi:

$$
Z "=6,56 \times 1+3,26 \times 2+6,72 \times 3+1,05 \times 4
$$

Keterangan:

$$
\begin{array}{ll}
\text { Z" } & =\text { bankrupcy index } \\
\text { X1 } & =\text { working capital/total asset } \\
\text { X2 } & =\text { retained earnings } / \text { total asset } \\
\text { X3 } & =\text { earning before interest and taxes } / \text { total asset } \\
\text { X4 } & =\text { book value of equity/book value of total debt } .
\end{array}
$$

Klasifikasi perusahaan yang sehat dan bangkrut didasarkan pada nilai Z-score model Altman Modifikasi yaitu:

a. Jika nilai Z" < 1,1 maka termasuk perusahaan yang bangkrut.

b. Jika nilai $1,1<Z$ " $<2,6$ maka termasuk grey area (tidak dapat ditentukan apakah perusahaan sehat ataupun mengalami kebangkrutan).

c. Jika nilai Z" > 2,6 maka termasuk perusahaan yang tidak bangkrut.

\section{Rasio Pertumbuhan Perusahaan}

Pertumbuhan perusahaan mengindikasikan kemampuan perusahaan dalam mempertahankan kelangsungan usahanya. Pertumbuhan perusahaan dapat diproksikan dengan rasio pertumbuhan penjualan. Rasio ini mengukur seberapa baik perusahaan mempertahankan posisi ekonominya, baik dalam industrinya maupun dalam kegiatan ekonomi secara keseluruhan (Setyarno dkk., 2006). Perusahaan yang mengalami pertumbuhan menunjukkan aktivitas operasional perusahaan berjalan dengan semestinya sehingga perusahaan dapat mempertahankan posisi ekonominya dan kelangsungan hidupnya. Sementara perusahaan dengan rasio pertumbuhan penjualan negatif berpotensi besar mengalami penurunan laba sehingga manajemen perlu untuk mengambil tindakan perbaikan agar tetap dapat mempertahankan kelangsungan hidupnya.

Penjualan merupakan kegiatan operasi utama perusahaan. Penjualan perusahaan yang meningkat dari tahun ke tahun memberi peluang perusahaan untuk memperoleh peningkatan laba. Oleh karena itu, semakin tinggi rasio pertumbuhan penjualan perusahaan akan semakin kecil kemungkinan auditor untuk menerbitkan opini audit going concern (Setyarno dkk., 2006). 


\section{Debt Default}

Debt default didefinisikan sebagai kegagalan debitor (perusahaan) dalam membayar utang pokok dan atau bunganya pada waktu jatuh tempo. Manfaat status default hutang sebelumnya juga telah diteliti oleh Chen dan Church (1992), yang menemukan hubungan yang kuat status default dengan opini going concern. Dalam ISA 570, menyatakan bahwa posisi hutang atau hutang lancar bersih merupakan salah satu peristiwa atau kondisi yang dapat menimbulkan keraguan atas kemampuan perusahaan dalam mempertahankan kelangsungan hidup mereka. Oleh karena itu kegagalan dalam memenuhi kewajiban hutang dan atau bunga suatu perusahaan merupakan indikator going concern yang banyak digunakan oleh auditor dalam menilai kelangsungan hidup suatu perusahaan. Dapat dikatakan bahwa status hutang perusahaan merupakan faktor pertama yang akan diperiksa oleh auditor untuk mengukur kesehatan keuangan perusahaan. Ketika jumlah hutang perusahaan sudah sangat besar, maka aliran kas perusahaan tentunya banyak dialokasikan untuk menutupi hutangnya, sehingga akan mengganggu kelangsungan operasi perusahaan. Apabila hutang ini tidak mampu dilunasi, maka kreditor akan memberikan status default (Januarti, 2009).

\section{Analisis Rasio Keuangan}

Menurut Munawir (2007:37), “Analisis Rasio adalah suatu metode analisa untuk mengetahui hubungan dari pos-pos tertentu dalam neraca atau laporan laba rugi secara individu atau kombinasi dari kedua laporan tersebut". Analisis rasio keuangan merupakan salah satu jenis prosedur analitis yang dapat digunakan untuk mengevaluasi kondisi keuangan perusahaan dan kinerjanya yang menghubungkan dua angka akuntansi dan didapat dengan membagi satu angka dengan angka lainnya.

Rasio suatu perusahaan dapat dianalisis dengan 2 macam jenis perbandingan yaitu perbandingan internal yang membandingkan rasio keuangan sekarang dengan rasio terdahulu pada perusahaan yang sama dan perbandingan eksternal atau sumber rasio industri yang membandingkan antara rasio perusahaan dengan rasio industri perusahaan terkait. Menurut Hornedan Wachowicz (2009:234), analisis rasio keuangan dibagi menjadi 5 bagian, yaitu:

1. Rasio Likuiditas

2. Rasio Leverage

3. Rasio Cakupan

4. Rasio Aktifitas

5. Rasio Profitabilitas

\section{Rasio Likuiditas (Current Ratio)}

Current Ratio merupakan salah satu rasio yang paling umum digunakan untuk mengukur likuiditas atau kemampuan perusahaan untuk memenuhi kewajiban jangka pendek tanpa menghadapi kesulitan. Semakin besar current ratio menunjukkan semakin tinggi kemampuan perusahaan dalam memenuhi kewajiban jangka pendeknya (termasuk didalamnya kewajiban membayar dividen kas yang terutang). Unsur-unsur yang mempengaruhi nilai current ratio adalah aktiva lancar dan utang jangka pendek. Dalam hal ini aktiva lancar terdiri dari kas, piutang usaha, persediaan, dan aktiva lancar lainnya. Menurut Horne dan Wachowicz (2009:206) rasio likuiditas menunjukkan kemampuan perusahaan untuk membayar kewajiban jangka pendeknya dengan menggunakan aktiva lancarnya. Rumus untuk menghitung rasio lancar adalah sebagai berikut:

$$
\text { CurrentRatio }=\frac{\text { Aktiva lancar }}{\text { Kewajiban jangka pendek }}
$$

\section{Rasio Profitabilitas (Return on Assets)}

Salah satu cara untuk mengukur tingkat keuntungan yang dicapai perusahaan adalah dengan menggunakan rasio Return on Assets (ROA). Rasio ini mengukur kemampuan 
perusahaan menghasilkan laba bersih berdasarkan tingkat asset yang tertentu. ROA juga sering disebut juga sebagai Return On Investment (ROI). Horne dan Wachowicz (2009:222) mengatakan rasio ini merupakan rasio keuntungan yang menghubungkan laba dengan investasi. Rasio pengembalian atas total aktiva dihitung dengan membagi laba bersih sesudah pajak dengan total aktiva.Rumus untuk menghitung rasio lancar adalah sebagai berikut:

$$
R O A=\frac{\text { Laba bersih setelah pajak }}{\text { Total Ativa }}
$$

\section{Opini Audit Tahun Sebelumya}

Opini audit going concern tahun sebelumnya ini akan menjadi faktor pertimbangan penting auditor untuk mengeluarkan kembali opini audit going concern pada tahun berikutnya. Apabila auditor menerbitkan opini audit going concern tahun sebelumnya maka akan semakin besar kemungkinan perusahaan akan menerima kembali opini audit going concern pada tahun berjalan. Setelah auditor mengeluarkan opini going concern, perusahaan harus menunjukkan peningkatan keuangan yang signifikan untuk memperoleh opini bersih pada tahun berikutnya. Jika tidak mengalami peningkatan keuangan maka pengeluaran opini audit going concern dapat diberikan kembali. Susanto (2009) dalam penelitiannya juga memperkuat bukti mengenai opini audit going concern yang diterima tahun sebelumnya dengan opini audit going concern tahun berjalan. Apabila pada tahun sebelumnya auditor telah menerbitkan opini audit going concern, semakin besar kemungkinan auditor untuk menerbitkan kembali opini audit going concern pada tahun berikutnya. Hal ini menunjukkan bahwa auditor dalam memberikan opini audit akan mempertimbangkan opini audit tahun sebelumnya. Karenanya, status default dapat meningkatkan kemungkinan auditor mengeluarkan laporan going concern.

\section{Kepatuhan Perusahaan pada Hukum dan Peraturan}

Menurut Rumokoy (2011), PT (Perseroan Terbatas) adalah subjek hukum mandiri yang oleh hukum dibekali dengan hak dan kewajiban yang tidak ubahnya dari hak dan kewajiban yang dimiliki oleh seorang manusia. Oleh karena PT adalah subjek hukum mandiri, maka keberadaannya tidak tergantung dari keberadaan pemegang sahamnya maupun anggota ddireksi dan dewan komisaris. Sekalipun mereka berganti atau diganti, pergantian tersebut tidak mempengaruhi keberadaan PT selaku persona standi in judicio.

Layaknya sebuah badan hukum, maka PT wajib memenuhi kewajiban-kewajiban yang disepakatinya berdasarkan perjanjian-perjanjian yang telah dibuatnya. Bila dia cidera janji, maka PT itu dapat dipertanggungjawabkan secara kontraktual (contractuele aansprakelijkheid). Juga dapat terjadi bahwa PT melakukan perbuatan melawan hukum dan oleh karena itu dia bertanggung jawab atas perbuatannya. Dalam hal ini terdapat pertanggungjawaban bukan kontraktual (buitencontractuele aansprakelijkheid).

Dalam melaksanakan upaya hukum secara perdata, dikenal salah satunya adalah upaya hukum pengajuan gugatan bagi pihak yang dirugikan karena tindakan pihak lain. Demikian halnya dengan subjek hukum mandiri, PT berhak mengajukan gugatan atapun diajukan gugatan atas tindakannya. Disamping gugatan yang bersifat umum, maka terdapat gugatan perseroan, yakni gugatan yang khusus terbit dalam hukum perseroan, bukan dari hukum acara pada umumnya. Bahkan hal yang sama secara mutatis mutandis juga berlaku dalam bidang pidana, sehingga muncul pula apa yang dapat disebut sebagai dakwaan perseroan. 


\section{Pengaruh Kondisi Keuangan terhadap Opini Going Concern}

Kondisi keuangan perusahaan menggambarkan tingkat kesehatan perusahaan sesungguhnya (Ramadhany, 2004). Mckeown et al (1990) menemukan bahwa auditor hampir tidak pernah memberikan opini audit going concern pada perusahaan yang tidak mengalami kesulitan keuangan. Setyarno dkk (2006) menyatakan bahwa semakin buruk kondisi keuangan perusahaan maka semakin besar probabilitas perusahaan menerima opini going concern. Dengan menggunakan model prediksi Zscore Altman, hasil penelitian Ramadhany (2004) selaras dengan penelitian Mc Kweon, Carcello dan Neal.

$\mathrm{H}_{1}$ : Kondisi keuangan berpengaruh terhadap pemberian opini audit going concern.

\section{Pengaruh Pertumbuhan Perusahaan terhadap Opini Going Concern}

Pertumbuhan perusahaan mengindikasikan kemampuan perusahaan dalam mempertahankan kelangsungan usahanya. Perusahaan yang mengalami pertumbuhan menunjukkan aktivitas operasional perusahaan berjalan dengan semestinya sehingga perusahaan dapat mempertahankan posisi ekonominya dan kelangsungan hidupnya, sedangkan perusahaan dengan negative growth mengindikasikan kecenderungan yang lebih besar ke arah kebangkrutan (Altman, 1968). Penelitian Fanny dan Saputra (2005) serta Setyarno dkk. (2006) menemukan bahwa pertumbuhan perusahaan tidak berpengaruh signifikan pada opini audit going concern.

$\mathrm{H}_{2}$ : Pertumbuhan perusahaan berpengaruh terhadap pemberian opini audit going concern

Pengaruh debt default terhadap Opini Going Concern

Januarti (2007) serta Ramadhany (2004) menunjukkan bahwa variabel debt default signifikan berpengaruh terhadap pemberian opini going concern. Hasil penelitian ini konsisten dengan penelitian terdahulu yang dilakukan oleh Chen dan Church (1992) yang menemukan bukti yang kuat antara pemberian status debt default dengan masalah going concern. Hal ini diperkuat dengan penggunaan indikasi kegagalan dalam memenuhi hutang dan atau bunga sebagai indikator bagi auditor untuk menilai kelangsungan hidup perusahaan. $\mathrm{H}_{3}$ : Debt default berpengaruh positif terhadap pemberian opini audit going concern

\section{Pengaruh Rasio Likuiditas (CR) terhadap Opini Going Concern}

Jika perusahaan memiliki likuiditas (diproksikan dengan current ratio) yang baik, maka kemungkinan untuk dapat meneruskan aktivitas usahanya akan lebih besar, sehingga kemungkinan untuk memperoleh opini going concern akan lebih sedikit. Penyataan tersebut diperkuat dengan hasil penelitian yang dilakukan oleh Januarti dan Fitrianasari (2008) yang menemukan bukti bahwa rasio likuiditas berpengaruh signifikan terhadap penerimaan opini audit going concern.

$\mathrm{H}_{4}$ : Rasio likuditas berpengaruh terhadap pemberian opini audit going concern.

\section{Pengaruh Rasio Profitabilitas (RoA) terhadap Opini Going Concern}

Ketika perusahaan mempunyai profitabilitas (diproksikan dengan $R o A$ ) yang tinggi diharapkan dapat memperoleh laba yang tinggi, sehingga kemungkinan kecil bagi perusahaan untuk memperoleh opini going concern. Hasil penelitian yang mendukung pernyataan tersebut adalah penelitian Susanto (2009) bahwa RoA berpengaruh signifikan terhadap penerimaan opini audit going concern.

$\mathrm{H}_{5}$ : Rasio profitabilitas berpengaruh terhadap pemberian opini audit going concern.

\section{Pengaruh opini audit tahun sebelumnya terhadap Opini Going Concern}

Apabila auditor menerbitkan opini audit going concern tahun sebelumnya maka akan semakin besar kemungkinan perusahaan akan menerima kembali opini audit going concern pada tahun berjalan. Penelitian Rahayu (2007) berhasil membuktikan bahwa opini audit tahun sebelumnya mempunyai pengaruh yang signifikan terhadap pemberian opini audit going concern. 
$\mathrm{H}_{6}$ : Opini audit tahun sebelumnya berpengaruh terhadap pemberian opini audit going concern.

\section{Pengaruh Kepatuhan perusahaan pada Hukum dan Peraturan terhadap Opini Going} Concern

Menurut Arens dan Loebbecke (1997:53) menyatakan bahwa perkara pengadilan, gugatan hukum atau masalah serupa yang sudah terjadi yang dapat membahayakan kemampuan perusahaan dalam beroperasi merupakan salah satu faktor dapat menimbulkan ketidakpastian mengenai kelangsungan hidup perusahaan.

$\mathrm{H}_{7}$ : Kepatuhan perusahaan pada hukum dan peraturan berpengaruh terhadap pemberian opini audit going concern.

\section{METODE PENELITIAN}

Data sekunder dalam penelitian ini menggunakan data dari laporan keuangan auditan perusahaan yang terdaftar di Bursa Efek Indonesia (BEI) pada tahun 2014 yang diperoleh dari laman BEI yaitu www.idx.co.id. Populasi dalam jumlah ini yaitu semua perusahaan yang terdaftar di Bursa Efek Indonesia pada tahun 2014, dan sampelnya adalah perusahaan manufaktur yang terdaftar di BEI dan pengumpulan sampelnya dengan menggunakan metode purposive sampling.

Tabel 1. Pengumpulan sampel

\begin{tabular}{|c|c|c|}
\hline No & Kriteria & Jumlah \\
\hline 1. & Perusahaan yang terdaftar di BEI periode 2014 & 506 \\
\hline 2. & Perusahaan yang delisting selamaperiode 2014 & -1 \\
\hline 3. & $\begin{array}{l}\text { Perusahaan tidak menerbitkan laporan keuangan } \\
\text { beserta laporan auditor independen secara lengkap }\end{array}$ & -20 \\
\hline & JumlahSampelAkhir & 485 \\
\hline
\end{tabular}

Sumber: Olahan penulis

\section{Definisi Operasional Variabel}

1. Kondisi keuangan perusahaan

Kondisi keuangan perusahaan dapat menggambarkan tingkat kesehatan perusahaan yang sesungguhnya (Ramadhany, 2004). Mckeown et al (1990) menemukan bahwa auditor hampir tidak akan pernah memberikan opini audit going concern pada perusahaan yang tidak mengalami kesulitan keuangan. Dalam penelitian ini kondisi keuangan perusahaan diproksikan dengan menggunakan model prediksi kebangkrutan Altman Z-Score modifikasi. Rumus yang digunakan adalah :

Keterangan:

$$
Z^{\prime \prime}=6,56 X_{1}+3,26 X_{2}+6,72 X_{3}+1,05 X_{4}
$$

Z" = bankrupcy index

$\mathrm{X}_{1} \quad=$ working capital/total asset

$\mathrm{X}_{2} \quad=$ retained earnings / total asset

$\mathrm{X}_{3} \quad=$ earning before interest and taxes/total asset

$\mathrm{X}_{4}=$ book value of equity/book value of total debt.

Nilai $\mathrm{Z}$ diperoleh dengan menghitung keempat rasio tersebut berdasarkan data pada neraca dan laporan laba/rugi dikalikan dengan koefisien masing-masing rasio kemudian dijumlahkan hasilnya. Hasil perhitungan Z-Score ini berupa skala rasio. Klasifikasi 
perusahaan yang sehat dan bangkrut didasarkan pada nilai Z-score model Altman Modifikasi yaitu:

a. Jika nilai Z" $<1,1$ maka termasuk perusahaan yang bangkrut.

b. Jika nilai $1,1<Z$ " $<2,6$ maka termasuk grey area (tidak dapat ditentukan apakah

Perusahaan sehat ataupun mengalami kebangkrutan).

c. Jika nilai Z" > 2,6 maka termasuk perusahaan yang tidak bangkrut.

2. Pertumbuhan perusahaan

Pertumbuhan perusahaan mengindikasikan kemampuan perusahaan dalam mempertahankan kelangsungan usahanya. Pertumbuhan perusahaan dapat diproksikan dengan rasio pertumbuhan penjualan. Rasio ini mengukur seberapa baik perusahaan mempertahankan posisi ekonominya, baik dalam industrinya maupun dalam kegiatan ekonomi secara keseluruhan (Setyarno dkk., 2006). Data ini diperoleh dengan menghitung sales growth ratio berdasarkan laporan laba/rugi masing-masing auditee. Hasil perhitungan rasio pertumbuhan penjualan disajikan dengan skala rasio.

$$
\text { PertumbuhanPenjualan }=\frac{\text { PenjualanBersih } h_{1}-\text { PenjualanBersih }_{t-1}}{\text { PenjualanBersih }{ }_{t-1}}
$$

\section{Debt default}

Debt default atau kegagalan dalam membayar hutang yang didefinisikan sebagai kelalaian atau kegagalan perusahaan dalam membayar hutang pokok atau bunganya pada saat jatuh tempo (Chen dan Church 1992). Variabel ini diukur dengan menggunakan metode dummy, angka 1 untuk debt default, angka 0 untuk tidak debt default untuk menunjukkan apakah perusahaan dalam keadaan default atau tidak.

4. Rasio lancar

Jika perusahaan memiliki likuiditas (diproksikan dengan current ratio) yang baik, maka kemungkinan perusahaan untuk dapat meneruskan aktifitas perusahaannya akan semakin besar, sehingga kemungkinan perusahaan mendapatkan opini audit going concern akan sedikit (Januarti dan Fitrianasari, 2008). Rasio lancar (current ratio) digunakan untuk mengukur kemampuan perusahaan untuk memenuhi kewajiban jangka pendeknya dengan menggunakan aktiva lancarnya. Rasio lancar merupakan satu dari rasio likuiditas yang paling umum dan sering digunakan. Semakin tinggi rasio lancar perusahaan, maka akan semakin besar kemampuan perusahaan dalam membayar berbagai tagihan jangka pendkenya (Horne dan Wachowicz (2009:206).

\section{Rasio ROA}

$$
C R=\frac{\text { AsetLancar }}{\text { KewajibanLancar }}
$$

Ketika perusahaan mempunyai profitabilitas (diproksikan dengan $R o A$ ) yang tinggi diharapkan memperoleh laba yang tinggi, sehingga kemungkinan kecil perusahaan mendapatkan opini audit going concern (Januarti dan Fitrianasari, 2008). Indikator profitabilitas yang digunakan dalam penelitian ini yaitu Return on asset (ROA). Semakin besar Return on Asset menunjukkan efektifitas perusahaan dalam menggunakan aktiva mereka untuk menghasilkan nominal penjualan mereka (Horne dan Wachowicz (2009:224).

$$
R o A=\frac{\text { Lababersihsetelahpajak }}{\text { TotalAset }}
$$




\section{Opini audit tahun sebelumnya}

Opini audit going concern tahun sebelumnya ini akan menjadi faktor pertimbangan penting auditor untuk mengeluarkan kembali opini audit going concern pada tahun berikutnya. Variabel ini diukur dengan menggunakan variabel dummy. Jika perusahaan menerima opini audit going concern (GCAO) pada tahun sebelumnya akan diberi kode 1 sedangkan jika perusahaan menerima opini audit non going concern (NGCAO) akan diberi kode 0 .

7. Kepatuhan perusahaan pada hukum dan peraturan

Menurut Arens dan Loebbecke (1997:53) menyatakan bahwa perkara pengadilan, gugatan hukum atau masalah serupa yang sudah terjadi yang dapat membahayakan kemampuan perusahaan dalam beroperasi merupakan salah satu faktor yang dapat menimbulkan ketidakpastian mengenai kelangsungan hidup perusahaan. Variabel ini diukur dengan menggunakan variabel dummy. Jika perusahaan memliki gugatan hukum (LS) yang masih belum final pada tahun berjalan akan diberi kode 1 sedangkan jika perusahaan tidak memiliki gugatan hukum yang belum final (LS) akan diberi kode 0 .

8. Opini audit going concern

Opini audit going concern adalah opini going concern unqualified/qualified dan going concern disclaimer opinion yang jika pengungkapan pada peristiwa/kondisi ketidakpastian material dilakukan secara tidak penuh (ISA 570.20). Audit unqualified dengan going concern audit report (GCAR) yang merupakan variabel dummy yang dilambangkan dengan 1 dan 0 bila opini tersebut audit unqualified tanpa going concern audit report (GCAR). Data ini diperoleh dengan cara menganalisis Laporan Auditor Independen pada tahun pengamatan yaitu tahun 2014.

\section{Metode Analisis}

Teknik yang digunakan dalam penelitian ini adalah analisis regresi logistic. Dalam logictic regression selain mengabaikan uji normalitas juga tidak mensyaratkan uji heterokedastisitas. Logistic regression dipakai apabila asumsi multivariate normal distribution tidak dapat dipenuhi. Sebelum pengujian hipotesis, terlebih dahulu dilakukan analisis statistik deskriptif untuk mengetahui karakteristik dari sampel yang digunakan. Statistik deskriptif meliputi jumlah sampel, nilai maksimum, nilai minimum, mean dan standar deviasi. Model logistic regression yang akan digunakan dalam penelitian ini disajikan sebagai berikut ini :

$$
\begin{aligned}
\operatorname{Ln} \frac{G C}{1-G C}=a & +\beta_{1} F D+\beta_{2} G R O W T H+\beta_{3} D E F A U L T+\beta_{4} C R+\beta_{5} R O A+\beta_{6} O P I N I+\beta_{7} L A W \\
& +\epsilon
\end{aligned}
$$

Keterangan :

$\begin{array}{ll}\operatorname{Ln} \frac{G C}{1-G C} & =\text { Opini Audit Going Concern } \\ a & =\text { Konstanta } \\ \beta_{1} F D & =\text { Kondisi keuangan (Altman Z score modifikasi) } \\ \beta_{2} G R O W T H & =\text { Pertumbuhan perusahaan } \\ \beta_{3} D E F A U L T & =\text { Debt default } \\ \beta_{4} C R & =\text { Rasio lancar } \\ \beta_{5} R O A & =\text { Return on Asset } \\ \beta_{6} O P I N I & =\text { Opini audit going concern tahun sebelumnya } \\ \beta_{7} L A W & =\text { Gugatan hukum pada perusahaan } \\ \epsilon & =\text { Error perusahaan i pada tahun t }\end{array}$




\section{HASIL DAN PEMBAHASAN \\ Statistik Deskriptif}

Statistik deskriptif berfungsi untuk mendiskripsikan atau memberi gambaran terhadap variabel penelitian yang diteliti melalui data sampel atau populasi dengan cara penyajian data melalui penjelasan pengelompokan berdasarkan N, minimum, maksimum, mean,standard deviasi.

Tabel 2. Statistik Deskriptif

\begin{tabular}{lrrrrr}
\hline & & & & & \multicolumn{1}{c}{ Std. } \\
& $\mathrm{N}$ & Minimum & Maximum & Mean & Deviation \\
\hline GC & 485 & 0 & 1 &, 09 &, 288 \\
FD & 485 & $-255,08$ & 3499,03 & 18,2403 & 218,21263 \\
GROWTH & 485 &,- 96 & 11,32 &, 2025 & 1,01027 \\
DEFAULT & 485 & 0 & 1 &, 07 &, 256 \\
CR & 485 &, 00 & 464,98 & 6,0675 & 32,49738 \\
ROA & 485 &,- 51 & 4,02 &, 0448 &, 20876 \\
OPINI & 485 & 0 & 1 &, 09 &, 288 \\
LAW & 485 & 0 & 1 &, 25 &, 433 \\
Valid N (listwise) & 485 & & & & \\
\hline
\end{tabular}

Sumber: data diolah SPSS

Statisik yang digunakan untuk menilai model fit adalah dengan menggunakan fungsi Likelihood L yang merupakan sebuah probabilitas bahwa model yang dihipotesiskan menggambarkan data input yang berdasarkan kriteria :

$\mathrm{H}_{0}$ : Model yang di hipotesiskan fit dengan data

$\mathrm{H}_{1}$ : Model yang di hipotesiskan tidak fit dengan data

Untuk menguji $\mathrm{H}_{0}$ dan $\mathrm{H}_{1}$, L ditransformasikan menjadi -2LogL. Statistik -2LogL juga disebut likelihood rasio $X^{2}$ statistics, dimana distribusi dengan degree of freedom (df) $n-$ $\mathrm{q}, \mathrm{q}$ adalah jumlah parameter dalam model.

Tabel 3. Pengujian Likelihood

\begin{tabular}{llrr}
\hline \multirow{3}{*}{ Iteration } & & & \multicolumn{2}{c}{ Coefficients } \\
\cline { 3 - 4 } Step 0 & & & \multicolumn{2}{c}{ Constant } \\
\cline { 3 - 4 } & 1 & 316,495 & $-1,637$ \\
& 2 & 295,877 & $-2,166$ \\
& 3 & 295,080 & $-2,297$ \\
& 4 & 295,078 & $-2,305$ \\
& 5 & 295,078 & $-2,305$ \\
\hline
\end{tabular}

a. Constant is included in the model.

b. Initial -2 Log Likelihood: 295,078

c. Estimation terminated at iteration number 5 because parameter estimates changed by less than ,001.

Sumber: data diolah SPSS

Tabel 3 merupakan hasil output SPSS22 dalam pengujian -2LogL pertama yang hanya memasukkan koefisien konstan dan menghasilkan nilai -2LogL 295,078 dan memiliki distribusi $X^{2}$ dengan df 484 (485-1). Hal ini signifkan terhadap alpha 5\% dan hipotesi nol 
ditolak yang berarti model hanyadengan konstanta saja yang tidak fit dengan data (Ghozali, 20: 268).

\section{Uji R2 (Cox dan Snell's R Square)}

Cox dan Snell's R Square merupakan ukuran yang mencoba meniru ukuran R2 pada multiple regression yang didasarkan pada teknik estimasi likelihood dengan nilai maksimum kurang dari 1 (satu) sehingga sulit diinteprestasikan. Nagelkerke's R square merupakan modifikasi dari koefisien cox dan snell untuk memastikan bahwa nilainya bervariasi dari 0 (nol) sampai 1 (satu). Hal ini dilakukan dengan cara membagi nilai cox dan snell's R2 dengan nilai maksimumnya. Nilai Nagelkerke's R square dapat diinterprestasikan seperti nilai R2 pada multiple regression.

Tabel 4 di bawah menunjukkan kemampuan variabel independen dalam menjelaskan variabel dependennya dengan nilai cox snell's R square sebesar ,381 dan nilai nagelkerke R square sebesar ,837 yang berarti variabilitas variabel dependen yang dapat dijelaskan oleh variablitas variabel independen (FD, GROWTH, DEFAULT, CR, ROA, OPINI, LAW) sebesar, $837(83,7 \%)$, sedangkan 16,3\% sisanya dapat dijelaskan dengan variabel independen lainnya.

Tabel 4. Model Cox\& Snell R Square

\begin{tabular}{lccc}
\hline Step & $\begin{array}{c}-2 \text { Log } \\
\text { likelihood }\end{array}$ & $\begin{array}{c}\text { Cox \& Snell } \\
\text { R Square }\end{array}$ & $\begin{array}{c}\text { Nagelkerke R } \\
\text { Square }\end{array}$ \\
\hline 1 & $62,187^{\text {a }}$ &, 381 &, 837 \\
\hline
\end{tabular}

a. Estimation terminated at iteration number 8 because parameter estimates changed by less than ,001

Sumber: data diolah SPSS

\section{Uji Kelayakan Model (Hosmer and Lemeshow's Goodness of Fit Test)}

Tabel 5 di atas menunjukkan nilai probabilitas signifikansi sebesar $0,957(95,7 \%)$ yang mana nilainya jauh diatas 0,05 sehingga hipotesis 0 tidak dapat ditolak dan berarti model mampu memprediksi nilai observasinya atau dapat dikatakan model dapat diterima karena cocok dengan data observasinya.

Tabel 5. Hosmer and Lemeshow Test

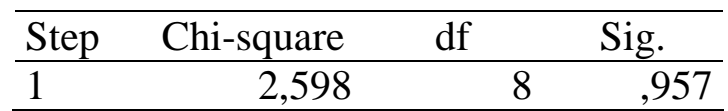

Sumber: olahan data SPSS

\section{Hasil Uji Regresi Binary Logistic}

Tabel 6. Hasil Binary Logistic

a. Variable(s) entered on step 1: FG,Growth, Default, CR, ROA, Opini Law 


\section{B S.E. Wald Df Sig. $\operatorname{Exp}(B)$}

\begin{tabular}{llrrrrrr}
\hline $\begin{array}{l}\text { Step } \\
1^{\mathrm{a}}\end{array}$ & FD &,- 001 &, 002 &, 059 & 1 &, 809 &, 999 \\
& GROWTH & - &, 938 & 1,572 & 1 &, 210 &, 308 \\
& DEFAULT & 4,730 & 1,090 & 18,850 & 1 &, 000 & 113,339 \\
& CR &, 007 &, 005 & 2,010 & 1 &, 156 & 1,007 \\
& ROA & - & 2,943 & 3,474 & 1 &, 062 &, 004 \\
& 5,485 & & & & & \\
& OPINI & 6,124 &, 875 & 48,947 & 1 &, 000 & 456,595 \\
& LAW &,- 788 & 1,123 &, 492 & 1 &, 483 &, 455 \\
& Constant & - &, 646 & 57,307 & 1 &, 000 &, 008 \\
& & 4,888 & & & & & \\
\hline
\end{tabular}

Sumber: olahan data SPSS

\section{Pembahasan}

a. Kondisi keuangan

Hasil uji binary logistic yang telah dilakukan menunjukkan bahwa variabel kondisi keuangan perusahaan (FD) tidak berpengaruh pada pemberian opini audit going concern. Hal ini dikarenakan variabel kondisi keuangan perusahaan mempunyai tingkat signifikansi ,809 yang mengindikasikan bahwa perusahaan dengan status bangkrut akan mempunyai peluang lebih kecil menerima opini going concern. Dari 485 sampel perusahaan yang mendapatkan opini going concern hanya sebesar 44 perusahaan dan sisanya mendapat opini non-going concern.

Tabel 7. Klasifikasi Kondisi Keuangan Sampel

\begin{tabular}{|c|c|c|c|c|c|c|c|c|}
\hline \multicolumn{3}{|c|}{ GC } & \multicolumn{3}{c|}{ NGC } & \multicolumn{3}{c|}{ SAMPEL } \\
\hline Kondisi & Jumlah & Presentase & Kondisi & Jumlah & Presentase & Kondisi & Jumlah & \\
\hline Bangkrut & 36 & $32 \%$ & \multicolumn{7}{c|}{ Bangkrut 77} & $68 \%$ & Bangkrut & 113 & $100 \%$ \\
\hline Sehat & 5 & $2 \%$ & sehat & 260 & $98 \%$ & sehat & 265 & $100 \%$ \\
\hline Grey & 3 & $3 \%$ & grey & 104 & $97 \%$ & grey & 107 & $100 \%$ \\
\hline \multicolumn{8}{|c|}{ Total Sampel } \\
\hline
\end{tabular}

Sumber: Olahan Data

Tabel 7 diatas menjelaskan klasifikasi kondisi keuangan perusahaan berdasarkan penerimaan opini going concern. Dari 113 perusahaan yang mengalami kebangkrutan berdasarkan hasil dari penghitungan analisis diskriminan Z-score, hanya terdapat $32 \%$ atau 36 perusahaan yang mendapatkan opini going concern dan $68 \%$ atau 77 perusahaan sisanya tidak menerima opini going concern pada laporan keuangan periode 2014-nya. Hasil ini merupakan temuan baru dari pengujian opini going concern yang menyimpulkan bahwa perusahaan dengan kondisi keuangan bangkrut masih lebih banyak didominasi oleh perusahaan dengan opini non-going concern sehingga kondisi keuangan perusahaan yang bangkrut tidak bisa menjamin perusahaan akan menerima opini going concern. Hasil ini merupakan temuan baru dari pengujian opini going concern yang bertolak belakang terhadap hasil dari penelitian para peneliti yang pada umumnya menemukan bahwa kondisi keuangan perusahaan mempunyai pengaruh terhadap pemberian opini going concern perusahaan.

b. Pertumbuhan perusahaan 
Hasil uji binary logistic yang telah dilakukan menunjukkan bahwa variabel pertumbuhan perusahaan (growth) tidak berpengaruh pada pemberian opini audit going concern. Hal ini dikarenakan variabel pertumbuhan perusahaan mempunyai tingkat signifikansi, 210 dan nilai koefisien regresi -1,177 yang mengindikasikan bahwa perusahaan dengan rate pertumbuhan negatif akan mempunyai peluang lebih kecil menerima opini going concern.

Tabel 8. Klasifikasi Rate Pertumbuhan Perusahaan Sampel

\begin{tabular}{|c|c|c|c|l|l|l|l|l|}
\hline \multicolumn{3}{|c|}{ GC } & \multicolumn{3}{c|}{ NGC } & \multicolumn{3}{c|}{ Sampel } \\
\hline Rate & Jumlah & & Rate & Jumlah & & Rate & Jumlah & \\
\hline Negatif & 27 & $17 \%$ & Negatif & 132 & $83 \%$ & Negatif & 159 & $100 \%$ \\
\hline Positif & 17 & $5 \%$ & Positif & 309 & $95 \%$ & Positif & 326 & $100 \%$ \\
\hline \multicolumn{8}{|c|}{ Total Sampel } & \multicolumn{3}{c|}{485} \\
\hline
\end{tabular}

Sumber: Olahan Data

Tabel 8 di atas menjelaskan klasifikasi rate pertumbuhan perusahaan berdasarkan penerimaan opini going concern. Terdapat 159 perusahaan dengan pertumbuhan perusahaan negatif, namun hanya ditemukan $17 \%$ atau 27 perusahaan yang mendapatkan opini going concern sedangkan $83 \%$ atau 132 perusahaan sisanya tidak menerima opini going concern pada laporan keuangan periode 2014. Dapat disimpulkan bahwa rasio pertumbuhan penjualan dengan rate negatif pada perusahaan tidak bisa menjamin bahwa perusahaan yang mengalami penurunan pada penjualannya akan selalu menerima opini going concern. Hasil penelitian ini didukung oleh penelitian dari Margaretta Fanny dan Sylfia Saputra (2005), Arry Pratama Rudyawan dan I Dewa Nyoman Badera (2009) yang juga menemukan bahwa pertumbuhan perusahaan tidak mempunyai pengaruh terhadap pemberian opini going concern perusahaan.

c. Debt default

Hasil uji binary logistic yang telah dilakukan menunjukkan bahwa variabel debt default (DEFAULT) berpengaruh positif pada pemberian opini audit going concern yang menunjukkan bahwa adanya peningkatan jumlah perusahaan dengan status default akan berdampak pula pada peningkatan pemberian opini audit going concern pada laporan keuangan perusahaan periode 2014. Hal ini juga ditunjukkan bahwa variabel debt default mempunyai tingkat signifikansi ,000 dan nilai koefisien regresi 4,730 yang mengindikasikan bahwa perusahaan dengan status debt default akan mempunyai peluang lebih besar menerima opini going concern.

Tabel 9 di bawah menjelaskan klasifikasi status debt default perusahaan berdasarkan penerimaan opini going concern. Dari 34 perusahaan dengan status debt default, mayoritas terdapat $82 \%$ atau 28 perusahaan yang menerima opini going concern sedangkan $18 \%$ atau 6 perusahaan sisanya tidak menerima opini going concern pada laporan keuangan periode 2014-nya yang menyimpulkan bahwa perusahaan dengan status debt default lebih banyak didominasi oleh perusahaan dengan opini going concern sehingga status debt default perusahaan dapat menjamin perusahaan akan menerima opini going concern. Hal ini selaras dengan penelitian yang pernah dilakukan oleh Ramadhany (2004), Margaretta Fanny dan Slyvia Saputra (2005), Setyarno dkk (2006), Susanto (2009) yang menemukan bahwa variabel debt default berpengaruh signifikan terhadap pemberian opini audit going concern. 
Tabel 9. Klasifikasi Status Debt Default Sampel

\begin{tabular}{|c|c|c|c|c|c|c|c|c|}
\hline \multicolumn{3}{|c|}{ GC } & \multicolumn{3}{|c|}{ NGC } & \multicolumn{3}{|c|}{ Sampel } \\
\hline Status & Jumlah & & Status & Jumlah & & Status & Jumlah & \\
\hline DD & 28 & $82 \%$ & DD & 6 & $18 \%$ & DD & 34 & $100 \%$ \\
\hline NDD & 16 & $4 \%$ & NDD & 435 & $96 \%$ & NDD & 451 & $100 \%$ \\
\hline & & & tal San & & & & 48 & \\
\hline
\end{tabular}

Sumber: Olahan Data

\section{d. Rasio lancar}

Hasil uji binary logistic yang telah dilakukan menunjukkan bahwa variabel rasio lancar (CR) tidak berpengaruh pada pemberian opini audit going concern. Hal ini dikarenakan variabel rasio lancar mempunyai tingkat signifikansi ,156 dan nilai koefisien regresi ,007 yang mengindikasikan bahwa perusahaan dengan rasio lancar yang bagus akan mempunyai peluang lebih kecil

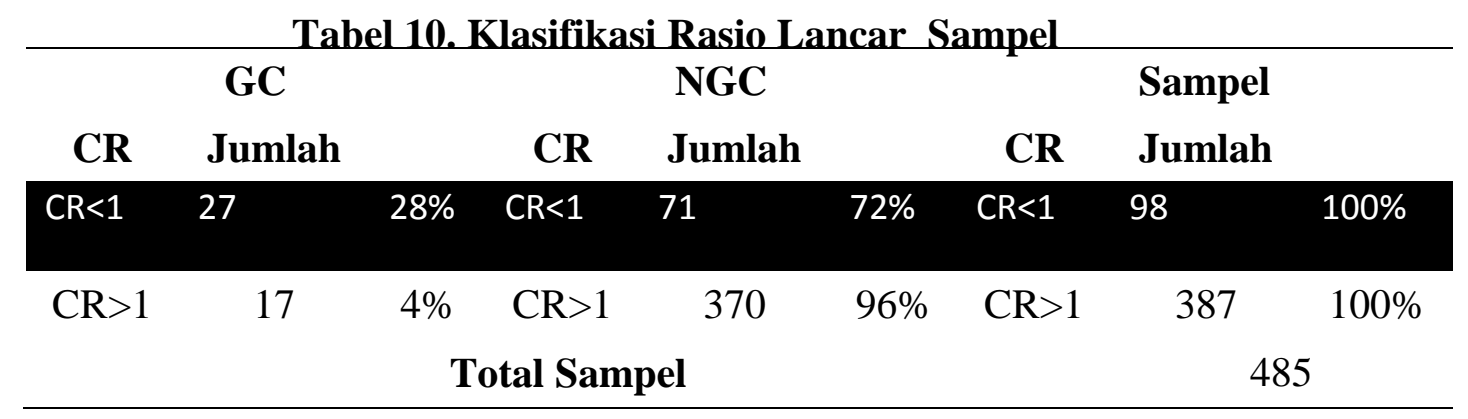

Sumber: Olahan Data

Tabel 10 di atas menjelaskan klasifikasi rasio lancar perusahaan berdasarkan penerimaan opini going concern. Terdapat 98 perusahaan yang mempunyai rasio lancar dibawah angka 1, namun hanya $28 \%$ atau 27 perusahaan yang menerima opini going concern sedangkan $72 \%$ atau 71 perusahaan sisanya tidak mendapatkan opini going concern pada laporan keuangan periode 2014-nya. yang menyimpulkan bahwa perusahaan dengan rasio lancar yang buruk lebih banyak didominasi oleh perusahaan dengan opini non-going concern sehingga rasio lancar yang buruk perusahaan tidak dapat menjamin perusahaan akan menerima opini going concern. Hal ini selaras dengan penelitian yang pernah dilakukan oleh Yulius Kurnia Susanto (2009), Puji Rahayu (2007) yang menemukan bahwa variabel rasio lancar tidak berpengaruh terhadap pemberian opini audit going concern.

e. Return on Assets

Hasil uji binary logistic yang telah dilakukan menunjukkan bahwa variabel Return on Assets (RoA) tidak berpengaruh pada pemberian opini audit going concern. Dikarenakan variabel Return on assets mempunyai tingkat signifikansi ,062 dan nilai koefisien regresi 5,485 yang menunjukkan bahwa perusahaan dengan Return on assets yang bagus akan mempunyai peluang lebih kecil menerima opini going concern. 
Tabel 11. Klasifikasi Return on Asset Sampel

\begin{tabular}{|c|c|c|c|c|c|c|c|c|}
\hline \multicolumn{3}{|c|}{ GC } & \multicolumn{3}{|c|}{ NGC } & \multicolumn{3}{|c|}{ Sampel } \\
\hline RoA & Jumlah & & RoA & Jumlah & & RoA & Jumlah & \\
\hline $\operatorname{Ro} A<1 \%$ & 33 & $24 \%$ & RoA $<1 \%$ & 102 & $76 \%$ & RoA $<1 \%$ & 135 & $100 \%$ \\
\hline $\operatorname{RoA}>1 \%$ & 11 & $3 \%$ & $\operatorname{RoA}>1 \%$ & 339 & $97 \%$ & $\operatorname{RoA}>1 \%$ & 350 & $100 \%$ \\
\hline & & & Total Sam & & & & 48 & \\
\hline
\end{tabular}

Sumber: Olahan Data

Tabel 11 di atas menjelaskan klasifikasi Return on Asset perusahaan berdasarkan penerimaan opini going concern. Dalam penelitian ini terdapat 135 perusahaan dengan Return on Asset di bawah 1\%, hanya $24 \%$ atau 33 perusahaan yang menerima opini going concern, sedangkan $76 \%$ atau 102 perusahaan lainnya tidak menerima opini going concern pada laporan keuangan periode 2014-nya yang menyimpulkan bahwa perusahaan dengan return on asset yang buruk lebih banyak didominasi oleh perusahaan dengan opini non-going concern sehingga return on asset yang buruk perusahaan tidak dapat menjamin perusahaan akan menerima opini going concern. Hal ini selaras dengan penelitian yang pernah dilakukan oleh Puji Rahayu (2007) yang menemukan bahwa variabel return on asset tidak berpengaruh terhadap pemberian opini audit going concern.

f. Opini audit tahun sebelumnya

Hasil uji binary logistic yang sudah dilakukan telah menunjukkan bahwa variabel opini audit tahun sebelumnya (OPINI) berpengaruh positif pada pemberian opini audit going concern yang menunjukkan bahwa adanya peningkatan jumlah perusahaan dengan opini audit going concern pada tahun sebelumnya akan berdampak pula pada peningkatan pemberian opini audit going concern pada laporan keuangan perusahaan periode 2014. Hal ini juga ditunjukkan bahwa variabel opini audit going concern tahun sebelumnya mempunyai tingkat signifikansi ,000 dan nilai koefisien regresi 6,124 yang menunjukkan bahwa perusahaan dengan opini audit going concern tahun sebelumnya akan mempunyai peluang lebih besar menerima opini going concern lagi.

Tabel 12 di bawah menjelaskan klasifikasi opini audit tahun sebelumnya perusahaan berdasarkan penerimaan opini going concern. Dari 44 perusahaan yang menerima opini audit going concern pada tahun sebelumnya terdapat $84 \%$ atau 37 perusahaan yang menerima opini going concern pada tahun berjalan sedangkan $16 \%$ atau 7 perusahaan sisanya tidak menerima opini audit going concern pada tahun berjalan yang menyimpulkan bahwa perusahaan dengan opini audit tahun sebelumnya yang buruk lebih banyak didominasi oleh perusahaan dengan opini non-going concern sehingga opini audit tahun sebelumnya yang buruk perusahaan tidak dapat menjamin perusahaan akan menerima opini going concern. Hal ini selaras dengan penelitian yang pernah dilakukan oleh Ramadhany (2004), Setyarno dkk (2006), Puji Rahayu (2007), Januarti dan Fitrianasari (2008), Susanto (2009), Yunida dan Wardhana (2013) yang menemukan bahwa variabel opini audit going concern tahun sebelumnya berpengaruh signifikan terhadap pemberian opini audit going concern. 
Tabel 12. Klasifikasi Opini Audit Tahun Sebelumnya Sampel

\begin{tabular}{|c|c|c|c|c|c|c|c|c|}
\hline \multicolumn{3}{|c|}{ GC } & \multicolumn{3}{|c|}{ NGC } & \multicolumn{3}{|c|}{ Sampel } \\
\hline Opini & Jumlah & & Opini & Jumlah & & Opini & Jumlah & \\
\hline GC-t & 37 & $84 \%$ & GC-t & 7 & $16 \%$ & GC-t & 44 & $100 \%$ \\
\hline NGC-t & 7 & $\begin{array}{r}2 \% \\
\mathbf{T}\end{array}$ & $\begin{array}{l}\text { NGC-t } \\
\text { tal San }\end{array}$ & el 434 & $98 \%$ & NGC-t & 441 & $100 \%$ \\
\hline
\end{tabular}

Sumber: Olahan Data

g. Kepatuhan perusahaan pada peraturan dan hukum

Hasil uji binary logistic yang sudah dilakukan telah menunjukkan bahwa variabel kepatuhan perusahaan pada peraturan dan hukum (LAW) tidak berpengaruh pada pemberian opini audit going concern. Hal ini dikarenakan variabel kepatuhan perusahaan pada peraturan dan hukum memiliki tingkat signifikansi ,483 dan nilai koefisien regresi -,788 yang menunjukkan bahwa perusahaan dengan perkara pengadilan, gugatan hukum atau masalah serupa akan mempunyai peluang lebih kecil menerima opini going concern lagi.

\begin{tabular}{|c|c|c|c|c|c|c|c|c|}
\hline \multicolumn{3}{|c|}{ GC } & & NGC & \multicolumn{4}{|c|}{ Sampel } \\
\hline LS & Jumlah & & LS & Jumlah & & $\mathbf{L S}$ & Jumlah & \\
\hline LS & 13 & $11 \%$ & LS & 108 & $89 \%$ & LS & 121 & $100 \%$ \\
\hline NLS & 31 & $9 \%$ & NLS & 333 & $91 \%$ & NLS & 364 & $100 \%$ \\
\hline & & To & al Sa & ipel & & & 48 & \\
\hline
\end{tabular}

Sumber: Olahan Data

Tabel 13 di atas menjelaskan klasifikasi perkara pengadilan, gugatan hukum, atau masalah serupaperusahaan berdasarkan penerimaan opini going concern. Dalam penelitian ini membuktikan bahwa dari 121 perusahaan yang mengalami masalah litigasi/hukum hanya terdapat $11 \%$ atau 13 perusahaan yang menerima opini going concern, sedangkan $89 \%$ atau 108 perusahaan sisanya tidak menerima opini going concern pada laporan keuangan periode 2014-nya yang menyimpulkan bahwa perusahaan dengan opini masalah litigasi/hukum lebih banyak didominasi oleh perusahaan dengan opini non-going concern sehingga masalah litigasi/hukum perusahaan tidak dapat menjamin perusahaan akan menerima opini going concern. Hasil ini merupakan temuan baru dari pengujian opini going concern perusahaan dengan masalah litigasi/hukum.

\section{KESIMPULAN dan SARAN Kesimpulan}

Berdasarkan hasil analisis penelitian yang sudah dilakukan diatas maka dapat disimpulkan bahwa :

1. Indikator keuangan perusahaan (debt default) dan indikator operasional dan lain-lain perusahaan (opini audit tahun sebelumnya) mempunyai pengaruh terhadap pemberian opini audit going concern.

2. Indikator keuangan perusahaan (kondisi keuangan, pertumbuhan perusahaan, rasio lancar, return on asset) dan indikator operasional dan lain-lain perusahaan (kepatuhan perusahaan terhadap hukum dan peraturan) tidak berpengaruh terhadap pemberian opini audit going concern. 


\section{Saran}

Adapun saran dari penulis atas keterbatasan dari penelitian ini, yaitu:

1. penelitian selanjutnya dapat menambah jumlah periode penelitian untuk mendapatkan periode sampel pengujian yang lebih representatif pada penelitian kedepannya mengingat masa transisi pada proses konvergensi ISA 570 mengenai asumsi kesinambungan usaha yang sudah mulai matang.

2. tingkat variabilitas pada variabel independennya (kondisi keuangan, pertumbuhan perusahaan, debt default, rasio lancar, return on asset, opini audit tahun sebelumnya, kepatuhan perusahaan pada hukum, dan peraturan) sebesar 83, 7\% dan 16, 3\% sisanya merupakan variabel yang diharapkan untuk dapat dipenuhi oleh peneliti selanjutnya

3. penelitian selanjutnya diharapkan peneliti melakukan pemisahan sektor industri dalam pengujian untuk dapat dilakukan proses identifikasi sektor industri yang paling banyak menerima opini going concern. 


\section{DAFTAR PUSTAKA}

Agoes, Sukrisno. 2012. Auditing: Petunjuk Praktis Pemeriksaan Akuntan oleh Akuntan Publik. Jakarta: Salemba Empat.

Altman, Edward. 1968. "Financial Ratios, Discriminant Analysis and the Prediction of Corporate Bankruptcy". Journal of Finance 23 September 1968, pp: 589-609.

Altman, Edward. 2000. Predicting Financial Distress of Companies: Revisiting the Z-score and ZETA Models. Working Paper Series, pp: 22-32.

Altman, E. and McGough, T. P. (1974). "Evaluation of a Company As a Going Concern". Journal of Accountancy. Vol. 138(6), pp: 50-57.

Arens, A. A. and Loebbecke, J. K. 1996. Auditing: Pendekatan Terpadu (Judul Asli : Auditing : An Integrated Approach).Edisi Revisi, Jilid 1. Penerjemah Amir Abadi Jusuf. Jakarta: Salemba Empat.

Boynton, C. W.,Johnson, N. R., Kell, G. W. 2002. Modern Auditing. Jakarta: Salemba Empat.

Bruynseels, Liesbeth. and Willekens, Marleen. 2006. Strategic Viability and Going-Concern Audit Opinions. Departement of Accounting, Financing, and Insurances. Belgium: Katholieke Universiteit Leuven.

Bursa Efek Indonesia (BEI). 2015. www.idx.co.id. Diakses 28 September 2015.

Carcello, Joseph. V. and Neal, Terry. L. 2000. "Audit Committee Composition and Auditor Reporting”. The Accounting Review. Vol. 75(4), pp: 453-467.

Chen, K. C. and Church, B. K. 1992. "Default on Debt Obligations and The Issuance of Going-Concern Opinions". Auditing: A Journal of Practice and Theory, pp: 30-49

Chen, Y., Weston, J. F., Altman, E. I. 1995. Financial Distress and Restructuring Models. Working Paper Series, pp: 57-75.

Fanny, M dan Saputra, S. 2005. "Opini Audit Going Concern: Kajian Berdasarkan Model Prediksi Kebangkrutan, Pertumbuhan Perusahaan, dan Reputasi Kantor Akuntan Publik". Simposium Nasional Akuntansi. Vol. 8, pp: 966-978.

Ghozali, Imam. 2009. Aplikasi Multivariate dengan Program IBM SPSS. Cetakan IV. Semarang: Badan Penerbit Universitas Diponegoro.

Ghozali, Imam. 2014. Ekonometrika: Teori, Konsep, dan Aplikasi dengan IBM SPSS 22. Semarang: Badan Penerbit Universitas Diponegoro.

Ikatan Akuntansi Indonesia. 2001. Standar Profesional Akuntan Publik Seksi 341.

$\begin{array}{llll}\text { International Federation } & \text { Of } & \text { Accountants } & \text { (IFAC). }\end{array}$ https://www.iaasb.org/system/files/publications/files/ISA-570-\%28Revised\%29.pdf. Diakses 15 september 2015. ISO 690.

Januarti, Indira. 2009. “Analisis Pengaruh Faktor Perusahaan, Kualitas Auditor, Kepemilikan Perusahaan terhadap Penerimaan Opini Audit Going Concern (Perusahaan Manufaktur yang Terdaftar di Bursa Efek Indonesia)".SIAE, hal: 5-9.

Januarti, I. dan Fitrianasari, E. 2008. "Analisis Rasio Keuangan dan Rasio Non Keuangan yang Mempengaruhi Auditor Dalam Memberikan Opini Audit Going Concern pada Auditee (Studi Empiris pada Perusahaan Manufaktur yang terdaftar di BEJ 20002005)". Jurnal MAKSI. Vol. 8(1), pp: 43-58.

Kuncoro, Mudrajat. 2003. Metode Riset untuk Bisnis dan Ekonomi. Bagaimana Meneliti dan Menulis Tesis. Jakarta: Erlangga.

LaSalle, R. E. and Anandarajan, A. 1996. “Auditors' Views On the Type of Audit Report Issued to Entities With Going Concern Uncertainties". Accounting Horizons. Vol. 10(2), pp: 51.

Linberg, Deborah. L. and Seifert, Deborah. L. 2011. "Moving Toward Convergence a Comparison of US Auditing Standard with International Standards on Auditing".CPA Journal. 
McKeown, J. C., Mutchler, J. F.,Hopwood, W. 1990. "Towards an Explanation of Auditor Failure to Modify the Audit Opinions of Bankrupt Companies". Auditing-a Journal Of Practice \& Theory. Vol. 10, pp: 1-13.

Mulyadi. 2002. Auditing. Jakarta: Salemba Empat

Mutchler, J. F. 1985. "A Multivariate Analysis of the Auditor's Going-Concern Opinion Decision". Journal of Accounting Research. Autumn. Vol. 23 (23), pp: 668-682.

Praptitorini, M. D. dan Januarti, I. 2007. "Analisis Pengaruh Kualitas Audit, Debt Default dan Opinion Shopping Terhadap Penerimaan Opini Going Concern”.Simposium Nasional Akuntansi X Makassar, pp: 6-9.

Pratama Rudyawan, A. R. R. Y. dan Nyoman Badera, I. D. 2009. "Opini Audit Going Concern: Kajian Berdasarkan Model Prediksi Kebangkrutan, Pertumbuhan Perusahaan, Leverage, dan Reputasi Auditor". Jurnal Ilmiah Akuntansi dan Bisnis. Vol. 4(2), pp: 49.

Purba, P. Marisi. 2009. Asumsi Going Concern: Suatu Tinjauan terhadap Dampak Krisis Keuangan atas Opini Audit dan Laporan Keuangan. Yogyakarta: Graha Ilmu.

Rahayu, P. 2007. "Assessing going concern opinion: a study based on financial and non financial informations (empirical evidence of Indonesian banking firms listed on JSX and SSX)". Simposium Nasional Akuntansi X Makassar, pp: 1-32.

Ramadhani, A. S dan Lukviarman, N. 2009. "Perbandingan Analisis Prediksi Kebangkrutan menggunakan Model Altman pertama, Altman Revisi, dan Altman Modifikasi dengan Ukuran dan Umur Perusahaan sebagai Variabel Penjelas (Studi pada Perusahaan Manufaktur yang Terdaftar di Bursa Efek Indonesia)".Jurnal Siasat Bisnis. Vol. 13(1), pp: $15-18$.

Ramadhany, Alexander. 2004. "Analsis Faktor-Faktor yang Mempengaruhi Penerimaan Opini Audit Going Concern pada Perusahaan Manufaktur yang Mengalami Financial Distress di Bursa Efek Jakarta”.Jurnal MAKSI. Vol. 4, pp: 146-160.

Rumokoy, Nike. K. 2011. Pertanggungjawaban Perseroan Selaku Badan Hukum dalam Kaitannya dengan Gugatan atas Perseroan (Dengan Undang-undang Nomor 40 Tahun 2007 Tentang Perseroan Terbatas sebagai Acuan Pembahasan. Vol. XIX(2), pp: 13.

Munawir, S. 2007. Analisa Laporan Keuangan. Liberty: Yogyakarta.

Setyarno., Budi, E., Januarti, I., dan Faisal. 2006. "Pengaruh Kualitas Audit, Kondisi Keuangan Perusahaan, Opini Audit Tahun Sebelumnya, Pertumbuhan Perusahaan Terhadap Opini Audit Going Concern". Simposium Akuntansi Nasional. Vol. 9(2), pp: 3-10.

Sugiyono. 2010. Statisika untuk Penelitian. Bandung: Alfabeta.

Susanto, Y. K. 2009. "Faktor-Faktor yang Mempengaruhi Penerimaan Opini Audit Going Concern pada Perusahaan Publik Sektor Manufaktur". Jurnal Bisnis dan Akuntansi. Vol. 11(3), pp: 155-173.

Tuanakotta, Theodorus. M. 2014. Audit Berbasis ISA. Jakarta: Salemba Empat.

Van Horne, C. J and Wachowicz, M. J. 2009. Prinsip-prinsip Manajemen Keuangan 1. Jakarta: Salemba Empat.

Yunida, Riswan. dan Wardhana, Wahyu. M. 2013. "Pengaruh Kualitas Audit, Kondisi Keuangan Perusahaan, Opini Audit Tahun Sebelumnya, Pertumbuhan Perusahaan terhadap Opini Audit Going Concern”. Jurnal INTEKNA. Tahun XIII (1), pp: 1-4. 